\title{
Economic Recession, College Athletics, and Issues of Diversity and Inclusion: When White America Sneezes, Black America Catches Pneumonia
}

\author{
Billy Hawkins \\ University of Georgia
}

I would like to preface my response with a brief background to the quote used in the title, "When White America sneezes, Black America catches pneumonia." The origin of this quote surfaced in the mid-1800s, when Austria's Prince Clemens von Metternich stated, "When France sneezes, Europe catches a cold" (Betts, 2010). Prince Metternich used this analogy to express characteristics of France's dominance during the early to mid-1800s and Europe's interdependence with France; thus, France's ability to determine or influence socioeconomic conditions in Europe.

Since its initial use, this quote has evolved and has been applied to explain conditions of socioeconomic, sociopolitical, and other conditions of interdependence throughout the world. For example, one adapted version of this quote states that, "When America sneezes, the world catches a cold." Another modified version of this analogy, which I chose to use, "When White America sneezes, Black America catches pneumonia," captures a direct relationship between Black and White America.

Despite the Marxist assumptions that are inherent in this quote, this statement is relevant in gauging issues of diversity and inclusion during this economic downturn, or, as I will attempt to address, this statement can be insightful when accessing the impact of the economic downturn on racial progress. I will focus mainly on racial progress in my response, not that gender issues are insignificant, but precisely because legislation through Title IX is an antidote that potentially insures action will be given to gender equity thus potentially lessening the degree of negative impact from this economic downturn. Furthermore, as it relates to racial progress, I also focus specifically on Black male athletes in my response due to the peculiar relationship these athletes share with predominantly white National Collegiate Athletic Association Division I Institutions; i.e., a relationship where Black male athletes represent the dominant athletic labor force that contributes to the revenue generated by these institutions' athletic departments.

Historically, as it relates to economic status and power, a significant percentage of Blacks in this country have shared an inverse relationship with whites. Dr. Manning Marable informs that ".... white affluence coexists with Black poverty; white 
state and corporate power are the product in part of Black powerlessness; income mobility for the few is rooted in income stasis for the many (Marable, 2000 p.2)." Furthermore, Dr. William Julius Wilson provides a macrosociological analysis of race and class, where he illustrates how race relations were structured by the economy and polity (Wilson, 1980). Finally, Dr. Antoine L. Joseph states that at varying times in the history of this country, "growing economic inequality fostered a rightward turn in American politics, which halted the march of racial progress" (Joseph, 2005 xiv). There has been a pattern where the state of Black America and its progress toward racial equality improves during periods of economic equality, but during economic downturns racial progress becomes stagnant or deteriorates inducing greater racial polarization (Joseph, 2005). Therefore, given previous behavioral patterns exhibited during various historical patterns of economic recessions in this country, one can conclude that efforts to increase diversity and inclusion can be in some way affected by the economic downturn we are currently experiencing.

To focus more narrowly on the impact of the economic downturn on issues of diversity and inclusion, in the context of collegiate athletics, Dr. Lapchick has elaborated on areas of gain and areas that need improvement. For several years, Dr. Lapchick and the Institute for Diversity and Ethics in Sport at the University of Central Florida, using a Race and Gender Report Card, have kept the nation abreast of the progress made in these areas in intercollegiate and professional sports. The results of these yearly report cards have increased our awareness of the progress and/or lack thereof occurring on and off the field in professional and collegiate sports. As Dr. Lapchick has expressed in the section of his paper entitled, "Who's running college sport," there is a lack of diversity and inclusion in the power elite positions of university presidents and conference commissioners (Lapchick, 2010). Obviously, these positions have the authority to either maintain the status quo, or with the right visionaries in these positions, they can set the tone for increasing diversity and inclusion. Thus far, according to the data Dr. Lapchick has presented, we have witnessed an abundance of the former and a scarcity in the latter.

Regarding racial progress, as Dr. Lapchick has stated, and I also concur that there are efforts being made at the coaching levels to increase the representation of Black head coaches, specifically, in college football, in general, and more specifically at the Bowl Championship Series (BCS) level. There are institutions that are finally going beyond their racial comfort zones and beyond the "good ole boy" network and recognizing the available talent that exists among the thousands of Black coaches previously relegated to assistant coaching positions. My hope and concerns are that the "peppering" of Black head coaches throughout collegiate sports is more than temporary concessions that evoke symbolic representation to silence the proponents of diversity and inclusion. I sincerely hope that these efforts assist in destroying racial myths and ideologies, while undoing years of discrimination and denial.

As a side note, I personally never bought into the myth that there was a lack of qualified Black coaches who were unable to successfully run these athletic corporations; i.e., win games, appeal to sponsors and donors, and represent their respective institutions. I see the deficiency residing where there is a lack of racially and culturally competent institutions and athletic programs with personnel who can hire Black head coaches into collegial environments and offer them the patience and longevity many White head coaches are afforded. 
Nevertheless, the recent hires Dr. Lapchick (2010) highlighted in his presentation (Willie Taggart at Western Kentucky, Larry Porter at Memphis, Michael London at University of Virginia, Strong at University of Louisville, Joker Phillips at University of Kentucky and James Franklin at University of Maryland) are monumental moves on behalf of predominantly white institutions whose administrators are coming to grips with the changing racial demographics of the U.S. and the racial progress this nation has made in electing its first "Black" President. We cannot take for granted the statement these institutions are making to their donors, alumni, and sponsors when they hire Black head coaches to run their multimillion dollar football programs. Gone are the days when head football coaches, specifically, had to simply prove themselves on the field by stacking up more wins than losses and fairing well in the postseason. Now, the corporate nature of intercollegiate athletics has demanded an evolution in the role of a head coach from being an on-the-field general, to becoming a savvy salesman and charismatic politician who appeases donors and sponsors who are, in most cases, predominantly white. I applaud these institutions for recognizing the need to hire the best man for the job, despite his racial heritage.

I feel optimistic about this pattern continuing. In addition, I must reiterate that without the continual forward-thinking and support among university administrative leaders, the possibility of hiring a Black head coach, or a minority coach, is unlikely.

Therefore, Dr. Lapchick's efforts to promote the "Eddie Robinson Rule" is a necessary component to ensure that minorities are at least represented in the candidate pool of potential hires, although it does not guarantee an increase in minority hires. Unfortunately, legislating morality in a capitalist society requires economic penalties to insure amicable results. Thus, penalties should be given to programs that are not meeting "race equity" protocol; similar to the National Football League's (NFL) Rooney Rule. Regrettably, it is inevitable that we must pass through the stage in which schools will only have a token "minority" candidate to meet requirements and avoid being penalized.

Shifting to "on-the-field" impact, one area that stands to incur a significant, potentially positive, impact due to the economic downturn is the increased need for the Black male body as a necessary premium for athletic performance and for the economic sustainability of major college athletics. Thus, diversity on the field will likely increase significantly especially at remote "ultra" White institutions, communities, and states; for example, at universities like Boise State, Utah, Notre Dame, and others that have recognized to compete at elite levels, they need this athletic commodity. Therefore, the needs to compete athletically at elite levels and maintain and sustain multimillion dollar athletic budgets will undoubtedly increase the pressure to recruit Black male athletes for the sports of football and basketball.

The reason I draw this conclusion is because of the predominance of Black males in the revenue generating sports of football and basketball that currently exist. Clearly, it is no secret that these two sports generate the most revenue for the leading NCAA Division I Institutions and that Black males play a dominant role as starters on these teams. For example, during the 2005-06 season Black male athletes represented $47 \%$ of NCAA Football Bowl Subdivision (FBS) and $59 \%$ of NCAA Division I basketball teams (Hawkins, 2010).

When we look closer at these sports, starting with football, during the 2007-08 season, of the top football programs generating at least $\$ 40$ million or 
more (Texas, Georgia, Virginia Tech, Florida, Auburn, etc,) Black male athletes represented 49-72\% of the team members. When we examine the 2008 and 2009 Bowl Championship Series, which generates over $\$ 170$ million, 6 of the 10 teams competing in the 5 bowl games, $60 \%$ of the players, on average, were Black athletes (Hawkins, 2010).

As it relates to NCAA men's basketball, a similar pattern exists where there is a need for the Black male body. During the 2007-08 season, on 11 of the top 25 teams in the country, $60 \%$ of the players, on average, were Black athletes (Hawkins, 2010). Of the teams that generated more than $\$ 10$ million, the majority of their teams were comprised of Black athletes. Furthermore, the NCAA Men's Basketball Tournament, which roughly generates $90 \%$ of the NCAA's revenue, benefits significantly from Black athletic talent. Black male athletes represented $59 \%$ of the players of the teams making the tournament, during the 2005-06 and 2006-07 seasons (Hawkins, 2010).

If one were to further examine the racial demographics of starters on both football and basketball teams, the percentage increases significantly where on several of the BCS football teams $100 \%$ of their starters on defense were Black and Black males made-up $100 \%$ of the starters on several of the men's teams making the NCAA basketball tournament.

Consequently, it is no surprise that many of these young men are approached by these institutions primarily for their athletic abilities. Economically challenging times will only increase the need for this athletic commodity. In addition, additional streams of revenue will need to increase, and the product - the Black male body-will need to be further commercialized to offset the losses incurred from reduced revenue generated from sponsors and donors. Again, this premium will create greater pressure on the athletic performance of Black male athletes, thus, a greater demand on recruiting Black males to generate revenue for institutions.

This increased need for Black male athleticism potentially creates contrasting experiences: a burden and a blessing. It creates a burden because the need for their athletic abilities will undoubtedly impact the academic performance of some Black male athletes. This is further compounded when a percentage of these same athletes' academic preparation does not meet the demands of academically rigorous institutions. This is often a systemic problem that originated long before they are recruited to be college athletes. But as we are witnessing, the lack of academic preparation is often ignored when elite athletic talent is present. Thus, ultimately, graduation rates among Black male athletes will linger below the average not because of lack of intelligence, but due to priorities.

These priorities are being established based on the messages young athletes are receiving when they are rewarded for their athletic abilities only and preferential treatment is then provided to assist them academically. This is further exacerbated when they witness the premium placed more on winning than academics. So, when coaches are fired for not winning regardless of the graduation rates of their athletes, we must consider the messages they are receiving. Priorities, that are being established when coaches express no loyalty to institutions or the educational process when they leave these institutions for a larger payday and more importantly they abandon young men who themselves have entrusted loyalty to these coaches who only seem to be in it for the money and fame. Again, we must consider the messages that are being sent and received. 
Therefore, the economic downturn will continue to mask the delusional state of athletic departments that think they can hide the academic unpreparedness of athletes for at least 2-3 years to withdraw as much athletic labor as needed in their quest to excel in the athletic arms race. The recent exposure of Florida State University's academic fraud and recruiting scandals by other institutions are not isolated incidents; they are simply the ones that are being caught. The practice of bending the rules is prevalent and the indiscretions associated with recruiting blue chip athletes increase because the stakes are high and the demands are great. Clearly, where there are glaring gaps between academic preparation and the academic demands and rigor of these institutions of higher education, the repeated episodes of special admits or admits with learning disabilities are shameful blemishes for institutions of higher education and most importantly for a developed nation.

Let me conclude by saying that the blessing piece is twofold: firstly, without athletic talents these athletes are getting an educational opportunity they may not have had otherwise, and secondly, despite being the work horses of athletic departments there are those who are performing well academically and graduating, as Dr. Lapchick has informed. Thus, amid these academic indiscretions and the pressure to perform each week for most of the school year, there are athletes competing, not only on the field, but in the classroom. Because of these contrasting experiences, I have mixed emotions: I hate the exploitation and academic neglect, but I value the opportunity these athletes are receiving to express themselves athletically with the possibility of getting an education.

Thus, in spite of the economic downturn, we cannot forget that reform is needed in collegiate athletics to reduce the athletic exploitation and academic neglect of all athletes in revenue generating sports. Unfortunately, the economic downturn can potentially slow the process of reform because the shift is away from human development and more toward economic sustainability and capital accumulation. Yet, we must remember that our business in higher education is in the development of life through teaching, service, and inquiring into the existence of things.

Without appearing overly negative about how the economic downturn will impact issues of diversity and inclusion, and more specifically racial progress, I can only hope that the changes this nation has made in electing its first Black president, will provide an inoculation from the virus of racial stagnation which has incurred previously when "White America sneezes."

\section{References}

Betts, R.F. (2010). Europe in Retrospect: A Brief History of the Past Two Hundred Years. Retrieved from http://www.britannia.com/history/euro/1/3_2.html.

Hawkins, B.J. (2010). The New Plantation: Black Athletes, College Sports, and Predominantly White NCAA Institutions. NY: Palgrave Macmillan.

Joseph, A.L. (2005). The Dynamics of Racial Progress: Economic Inequality and Race Relations since Reconstruction, Armonk, N.Y., and London: M. E. Sharpe, xiv.

Lapchick, R. (2010). The Effect of the Economic Downturn on College Athletes and Athletic Departments on Issues of Diversity and Inclusion. Journal of Intercollegiate Sport, 3 , 81-95.

Marable, M. (2000). How Capitalism Underdeveloped Black America, (p. 2), Cambridge, MA: South End Press.

Wilson, W.J. (1980). The Declining Significance of Race: Blacks and Changing American Institutions, 2nd Edition, Chicago: University of Chicago Press. 